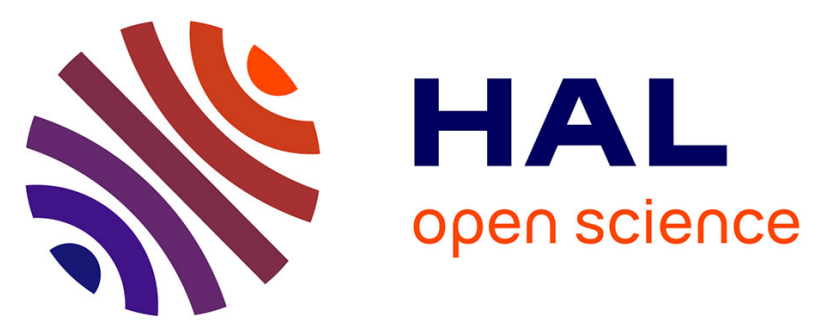

\title{
Contribution to the reappraisal of the mid Paleogene ichtyofauna of Western Africa with three new enigmatical elasmobranchs from Thanetian-Lutetian of Senegal
}

Bernard Siguendibo Sambou, Lionel Hautier, Raphael Sarr, Rodolphe Tabuce, Fabrice Lihoreau, Moustapha Thiam, Renaud Lebrun, Jérémy Martin, Henri Cappetta, Sylvain Adnet

\section{- To cite this version:}

Bernard Siguendibo Sambou, Lionel Hautier, Raphael Sarr, Rodolphe Tabuce, Fabrice Lihoreau, et al. Contribution to the reappraisal of the mid Paleogene ichtyofauna of Western Africa with three new enigmatical elasmobranchs from Thanetian-Lutetian of Senegal. Annales de Paléontologie, 2020, 106 (3), pp.102400. 10.1016/j.annpal.2020.102400 . hal-02992155

\section{HAL Id: hal-02992155 \\ https://hal.science/hal-02992155}

Submitted on 23 Nov 2020

HAL is a multi-disciplinary open access archive for the deposit and dissemination of scientific research documents, whether they are published or not. The documents may come from teaching and research institutions in France or abroad, or from public or private research centers.
L'archive ouverte pluridisciplinaire HAL, est destinée au dépôt et à la diffusion de documents scientifiques de niveau recherche, publiés ou non, émanant des établissements d'enseignement et de recherche français ou étrangers, des laboratoires publics ou privés. 
1 Contribution to the reappraisal of mid Paleogene ichtyofauna of Western Africa with

2 three new enigmatical elasmobranchs from Thanetian-Lutetian of Senegal.

3 Contribution à la réévaluation de l'ichtyofaune du Paléogène moyen en Afrique de

4 l'Ouest avec trois nouveaux élasmobranches énigmatiques du Thanétien-Lutétien du 5 Sénégal.

7 Bernard Siguendibo Sambou ${ }^{2}$, Lionel Hautier ${ }^{1}$, Raphael Sarr ${ }^{2}$, Rodolphe Tabuce ${ }^{1}$, Fabrice

8 Lihoreau $^{1}$, Moustapha Thiam ${ }^{2}$, Renaud Lebrun ${ }^{1}$, Jeremy E. Martin ${ }^{3}$, Henri Cappetta ${ }^{1}$, Sylvain 9 Adnet $^{1 *}$

${ }^{1}$ Institut des Sciences de l'Evolution, UMR5554, CNRS, IRD, EPHE, Université de

Montpellier, Montpellier, France

${ }^{2}$ Département de Géologie, Faculté des Sciences et Techniques, Université Cheikh Anta Diop de Dakar, B. P. 5005 Dakar, Sénégal

${ }^{3}$ Univ. Lyon, ENS de Lyon, Université Claude Bernard Lyon 1, CNRS, UMR 5276

Laboratoire de Géologie de Lyon: Terre, Planètes, Environnement, F-69342 46 Allée d'Italie,

Lyon, France 
Abstract.

We report here three new elasmobranch fossil taxa from Thanetian-Lower Lutetian nearshore marine deposits of northeastern (Matam region) and central-western (Sine-Saloum region) Senegal. These three new taxa represent the oldest species of the enigmatical elasmobranch Odontorhytis, the oldest putative representatives of marine potamotrygonid, and an uncertain dasyatoid genus with the smallest grinding dentition ever described. These new taxa, representing the second Cenozoic elasmobranch remains formally described from Senegal, broaden our understanding of their evolutionary and biogeographic history in the equatorial Eastern Atlantic during this time period. Their occurrences confirm hypothesised stratigraphically correlations between the top of Matam Fm. and the base of Lam Lam Fm., refine the marine connections between these two Senegalese regions, and suggest that these genera were broadly distributed within the shallow marine settings of the equatorial Eastern Atlantic during latest Paleocene - early Middle Eocene.

Keywords: Elasmobranch, new taxa, Paleogene, Senegal. 
Résumé.

49

50

52

53

54

55

Nous rapportons ici trois nouveaux taxa de fossiles d'élasmobranches des dépôts marins littoraux du Thanétien-Lutétien inférieur du Nord-Est (région de Matam) et du Centre-Ouest (région du Sine-Saloum) du Sénégal. Ces trois nouveaux taxa représentent les espèces les plus anciennes d'élasmobranches énigmatiques appartenant au genre Odontorhytis, aux potamotrygonides marins et à un dasyatoïde avec la plus petite denture broyeuse jamais décrite. Ces nouveaux taxa, complétant l'unique description d'élasmobranches cénozoïques nouveaux au Sénégal, élargissent notre compréhension de leur histoire évolutive et biogéographique de l'Atlantique Est équatorial au cours de cette période. Leurs occurrences confirment des corrélations stratigraphiques hypothétiques entre le sommet de la Formation de Matam et la base de la Formation de Lam Lam. Celles-ci affinent aussi les liens marins entre ces deux régions sénégalaises et leur comparaison avec des occurrences reconnues en Afrique du Nord et de l'Ouest suggèrent que ces genres étaient largement répartis et diversifiés dans les environnements marins peu profonds de l'Atlantique Est équatorial au cours du Paléocène terminal et du début de l'Éocène moyen.

Mots-clés: Elasmobranche, nouveaux taxa, Paléogène, Sénégal.

(6) 


\section{Introduction}

Biogeographic origins of African modern vertebrates have been the focus of considerable research since last decade in warm Paleogene period of West Africa. Among them, elasmobranch fossil record devoted to mid Paleogene was very partial with a unique description of taxa such as Lophobatis Cappetta, 1986, preliminary reports (Pascal, 1987; Cappetta and Traverse, 1988; Stevens et al., 2011), and/or ancient works that (e.g. Strömer, 1910, White, 1926, 1934, 1955). Biogeographic interpretations of past elasmobranch diversity in Central Western Atlantic during Paleogene have been mainly evidenced based on the richer northwestern (e.g. Morocco) and southwestern (e.g. Angola) African deposits (e.g. Arambourg, 1952; Noubhani and Cappetta, 1997; Dartevelle and Casier, 1943, 1959; Solé et al., 2018). However, a corresponding body of research is largely lacking for the Paleogene equatorial Eastern Atlantic elasmobranchs, despite the fact that nearly all of the known Cenozoic rocks along the West African coast are marine, especially near the Guinean Gulf. Indeed, reappraisal of the mid Paleogene Western African faunas is essential to better understand the elasmobranch evolution in the equatorial paleo-Atlantic. Currently, the Senegalese elasmobranch Cenozoic fossil record is only represented by mid Paleogene taxa from the phosphate ores of Matam (Pascal, 1987; Sambou et al., 2018; Sambou 2018) and Taïba (Hautier et al., 2012, 2014). Other associated marine vertebrate, including bony fish like amiid or scombrid (O-Leary et al. 2012, Cleason et al. 2015), sea cows and whales (Hautier et al., 2012) are recovered in Early-Middle Eocene from same or different localities (e.g. Gossas, Bargny). We report here, three new taxa of elasmobranchs with unambiguous dental morphologies that support biostratigraphical correlations between Formations from two 
main Senegalese areas: Matam (Pascal, 1987; Sambou et al., 2017; Sambou, 2018) and Kaolack in Sine-Saloum region (Tabuce et al., 2019). These new taxa contribute to the reappraisal of mid Paleogene fauna of Western Africa and improve understanding the diversification of modern elasmobranchs.

\section{Geological setting, material and methods.}

Most of the specimens were found in the phosphate ore of Ndendouri-Ouali Diala near Matam (sub-prefecture of Orkadiéré, Matam region, approximatively $15^{\circ} 18^{\prime} \mathrm{N}, 13^{\circ} 01^{\prime} \mathrm{W}$, see Sambou et al., 2017 for details) located on the left riverbank of the Senegal River, northeasternstern part of Senegal (Fig. 1). The studied material was collected in water-well cuttings during ancient campaigns of M. Pascal (see Pascal, 1987) that allowed to collect an amount of $450 \mathrm{~kg}$ of phosphatic sediment and $50 \mathrm{~kg}$ of sandy sediment in a series of wells (collecting H.C.) and from recent wells drilled manually in the subsoil of Ndendouri-Ouali Diala (collecting B.S.) and following a NW direction (see Sambou, 2018). Sambou et al. (2017) recently revised the faunas from the Gorgol and Matam Fm. outcropping in the phosphate ore of Matam as previously reported in Pascal (1987). 38 species of elasmobranch have been recognized in the different levels of the 20 well-drilling and 33 different samples along the Matam series (see Sambou et al., 2017 : Tab.1 for details). These faunas include several determined and undetermined species of Brachycarcharias, "Cretolamna", Protoginglymostoma, Ginglymostoma, Nebrius, Rhizoprionodon, Physogaleus, Triakis, Foumtizia, Rhynchobatus, Pristis, Anoxypristis, Eotorpedo, Lophobatis, Myliobatis, Rhinoptera, Leidybatis, Garabatis, Coupatezia, Ouledia and the three new taxa reported here. From these, five fossiliferous associations were identified along the available sedimentological successions (see Fig. 1), and confirmed the late Thanetian age of the top of the Gorgol Fm. (association 1 - lithological Unit 0), the Ypresian age of the phosphate 
deposits belonging to Matam Fm (rich associations 2-4, lithological Units 1-3), and the Lutetian age of the higher clay-limestone unit of Matam Fm. (association 5, lithological Unit 4).

The other specimens come from the water-well cuttings located at Sanghaye Bele village (14'16'55.5”N, 166'14.01'W, Fig. 1), north of Kaolack in the Sine-Saloum region (centralwestern part of Senegal, see Tabuce et al., 2019 for details). The fossiliferous deposits attributed to the Lam Lam Fm. correspond to coquina limestone and yellow to white clayey limestone alternating with marls. Material was recovered by soft acid attack (acetic $8 \%$ ) of 30 $\mathrm{kg}$ of sediments (see also Tabuce et al. 2019 for details). If the base of the Lam-Lam Formation is E8 in age (lower Lutetian), the top of the formation (Lam-Lam marls) yielded a rich planktonic foraminifera association that indicates the E9 biozone (top of lower Lutetian) (Flicoteaux 1974, Roger et al. 2009). These regional correlations indicate a confident lower Lutetian age (E8-E9 biozones, 49 to 45,8 Ma 44 M.a., Vandenberghe et al. 2012) for the fossiliferous level in water-well of Sanghaye Bele (see Tabuce et al. 2019 for correlations). Some elasmobranch remains were collected in the $30 \mathrm{~kg}$ of limestone and include for instance some teeth of Chiloscyllium sp., Nebrius cf. obliquus, ?Rhizoprionodon sp., Physogaleus sp., Rhynchobatus sp., Rhinobatos sp., Ouledia sp., ?Jacquhermania attiai, Arechia sp., Dasyatoid indet., Coupatezia sp. as well as two of the three new taxa described here. The elasmobranch assemblage from the coquina limestone of the Lam Lam Fm. in Sanghaye Bele would then be contemporaneous with the coquina limestone of the Ngolothie borehole near Kaolack (Tabuce et al. 2019) and most probably sub contemporaneous with the elasmobranch assemblage of the clay-limestone unit ending the Matam Fm. in Sambou et al. (2017).

FIG.1 here

\section{Systematic Palaeontology}


Institutional Abbreviations - Fossil material, including type series, is housed at the

144 University of Montpellier, France (abbreviations SES, MAM) or at the University Cheikh

145 Anta Diop of Dakar, Senegal (abbreviations SNSAN/2011/). Tooth terminology follows

146 Cappetta (2012)

147

148 Class CHONDRICHTHYES Huxley, 1880

149 Subclass ELASMOBRANCHII Bonaparte, 1838

150 SubCohort NEOSELACHII Compagno, 1977

151 Superorder BATOMORPHII Cappetta, 1980

152 Order MYLIOBATIFORMES Compagno, 1973

153 Superfamily DASYATOIDEA Compagno, 1973

154 ?Potamotrygonidae Garman, 1877

155 ?Styracurinae Carvalho et al., 2016

156

157 Atlantitrygon nov.gen.

158 Type species: Dasyatis sudrei Cappetta, 1972

159 Type material: Hototype: SES64, Sessao, Thanetian of Niger (Cappetta, 1972 : Plate 6 fig. 3 )

160 refigured in figure 2 A ; paratypes SES62-63, 65-67 (Cappetta, 1972 : Plate 6 fig. 1-2,4-6)

161 partially refigured in figure 2 B-D. 
Etymology: simplified Greek "Atlanti” refers to the past distribution of representatives, currently limited to tropical Atlantic sea along the western African coast, and Greek "trygon" meaning stingray.

Diagnosis: Dasyatoid genus characterized by gracile medium sized teeth with high crown compared to root, a development in height of the lingual zone and the lingual marginal face of crown (including the transversal keel); a long, slender cusp mesiodistally flattened and highlighted by an occlusal median crest, a junction between the undulating transverse keel and the median crest of cusp forming a three-pointed star in occlusale view ; a narrow lingual face and a concave labial face of crown with finely ornamented enameloid; a root with two sub-triangular lobes elongated transversally.

Occurrence: from Thanetian (Niger, Togo and Senegal) with A. sudrei to lower Lutetian (Senegal) with A. senegalensis nov. sp.

Discussion: Cappetta (1972) described Dasyatis sudrei from Sessao, Niger. At that time, diagnosis characters, e.g. the long slender cusp, were evaluated as enough peculiar compared to other species of Dasyatis s.l. to justify the creation of a new species (Cappetta, 1972: p. 207). The author suggested that this taxon could be close to genus Himantura, unknown at the fossil state in 1972. In fact, a slender long cusp is known in many male teeth belonging to some dasyatidspecies (e.g. Dasyatis, Hypanus) and many Urotrygonidae (e.g. Urobatis) and Urolophidae (e.g. Urolophus) but this long cusp is usually rooted on the edge of lingual zone and its top is delimited by the transversal keel that follows the upper borders of cusp. The upper face of cusp, often concave, belongs in fact to the labial face, contrary to what is observed in Atlantitrygon. The unique dasyatoid teeth that display a comparable "displaced" cusp are observable in living western Atlantic "Himantura" schmardae (Werner, 1904 : see Cappetta, 2012, fig. 410) recently attributed to genus Styracura Carvalho et al., 2016wich also 
includes S. pacifica (Beebe and Tee-Van, 1941). Both these marine species, recently included in Potamotrygonidae, are considered more closely related to freshwater potamotrygonins (Carvalho et al., 2016). The inclusion of Atlantitrygon in the marine Styracurinae thus remains hypothetic and is only based on global resemblances of the tooth shape and the presence of a displaced main cusp. However, the teeth of S. schmardae are easily distinguishable from Atlantitrygon nov. gen. by having a straight transversal keel, a second transverse keel, running more or less parallel to main one, a cusp without crest and a ornamentations absent, contrary to the condition seen in teeth of Atlantitrygon nov. gen. Finally, the unique combination of characters in Atlantitrygon nov. gen. does support the creation of this new fossil genus but its systematic position among the Potamotrygonidae remains nevertheless uncertain, partly because our limited knowledge of the dental variation in living batoid (Guinot et al., 2018).

Atlantitrygon senegalensis nov. sp.

Etymology: Refers to the country where the type series was found

Type material : Holotype Fig. 2 K, MAM-09 (well F0 9.18-9.3m, Unit 2 in Sambou et al., 2017) Ndendouri-Ouali Diala, ?Early Ypresian, Matam Fm.; Paratypes Fig. 2 F-J, MAM-04 to MAM-08 and MAM-10 to MAM-11 (well F0 9.18-9.30m, Unit 2 in Sambou et al., 2017) Ndendouri-Ouali Diala, ?Early Ypresian, Matam Fm

Additional material: a fifteen teeth from Lower Lutetian (E8-E9 biozones, 49 to 45,8 My) of Sine-Saloum region, Senegal and also partially figured Fig. 2 N-Q

Diagnosis: The new species distinguishes from the unique type species of genus by having teeth with higher transversal keel that looks as more protruding, undulated and often marked by three rounded pseudo cusplets in lingual view. Two of these cusplets are located at the 
margin while the third one, the highest, is situated in the cusp axis. Compared to the type species, ornamentation of the enameloid of the lingual and labial faces is more finely developed, especially under the transversal keel with an alveolar network shape.

Occurrence: Ypresian to Lower Lutetian of Matam and Lower Lutetian of Sine-Saloum regions, Senegal, possibly in the Ypresian of Mali (Tamaguilet) and Morocco (Ouled Abdoun)

Description: The tooth morphology is consistent with that of dasyatoids, a paraphyletic group that includes many different families of stingrays (e.g. DasyatidaeUrobatidae, Urolophidae, Urotrygonidae, Potamotrygonidae, Plesiobatidae) with no pavement-like arrangement. The dentition is monognathic heterodont with high-crowned teeth (e.g. Fig. 2 I), which decrease in size toward the commissure (e.g. Fig. 2 M, P). The holotype (Fig. 2 K) is a tooth probably located medially along the jaw. It displays a high crown (Fig. 2 K2) with robust cusp (Fig. 2 K2). In occlusal view (Fig. $2 \mathrm{~K} 1$ ), the crown is semi-oval in shape, broader than long, with a long, slender cusp with median crest on its occlusal part. This median crest does not reach the apex of cusp (Fig. 2K1). The crown has a high, transverse keel, which divides the crown into distinct labial and lingual parts (Fig. 2K1). The junction between the undulating transverse keel and the median crest of cusp forms a three-pointed star (Fig. 2 K1). The transverse keel is quite salient and forms an erected cutting edge. The upper part of the lingual face (below the transverse keel) and the labial face are fully ornamented. This ornamentation is quite delicate and organized as an alveolar network with larger alveolus on concave basin of the labial face (Fig. 2 K3). The upper part of the ornamented labial visor (labial border of labial face) is reduced to a straight crest that overhangs the lower part of the unornamented labial visor. The lower part of lingual face, also unornamented below the cusp axis, is relatively expanded marginally. The root is narrow in profile (Fig. $2 \mathrm{~K} 2$ ), of holaulacorhizous type with two short lobes separated by a low groove. A large central foramen opens in labial part of the 
nutritive groove. Tooth variability, in part due to heterodonty, mainly involves the general shape of the crown, which is sometimes subtriangular in shape (e.g. Fig. 2 I) with often a long slender cusp. This cusp is always present in all specimens suggesting no sexual heterodonty. In more anterior files, the crown sometimes displays a very high, undulating transverse keel that forms three pseudo rounded cusplets in lingual view (e.g. Fig. 2 L1, O1, N1). One of them is located at the junction between the transverse keel and the median crest of the cusp. Lingual ornamentations seemingly are absent on the lower part of lingual face and below the cusp axis of all specimens, conversely to the condition seen in the whole labial face and in the narrow band of lingual marginal face just under the transversal keel. In anterior teeth, this ornamented upper part of lingual face is sometimes set apart from the unornamented lower part by rounded transverse keels in lingual view (Fig. $2 \mathrm{~L}, \mathrm{~N}$ ). Enameloid ornamentation is quite delicate in the upper part of the lingual face (Fig. $2 \mathrm{H} 3$, L2) and could be organized as an alveolar network with larger alveolus on concave basin of the labial face (Fig. 2 K3, M2). This ornamentation reduces gradually near the keel and crests where it takes the form of lace when not abraded. The labial visor is merely variable, being often reduced to a salient and straight crest delimiting the labial border of the labial face. The basal view of the crown (Fig. $2 \mathrm{H} 2, \mathrm{I} 1, \mathrm{O} 2$ ) shows a broad and slightly convex crown rim at the outer part, which gradually narrows down to half of its width at the inner part. The crown-root junction is located in a shallow depression at the centre of the basal surface of the crown. The root is lower than the crown, of holaulacorhizous type with two lobes, which are triangular (fig. 2 I1, H2) to semicircular in shape (fig. 2 O2) in basal view. The root base has a well-developed and deep median nutritive groove that encloses a single large central foramen (fig. 2 M1, O2). No inner or outer foramina are discernible on the specimens. The lower Lutetian material from SineSaloum (fig. 2 N-P) is quite similar to the type series from Matam region (fig. 2 F-M) despite its poorer state of conservation. 
Discussion: Compared to A. sudrei, the new species A. senegalensis nov. sp. displays teeth with similar shape, but its transversal keel is higher, more protruding, undulated and often marked by three rounded pseudo cusplets in lingual view. Two of these cusplets are located at the margin while the third one, the most developed, is situated in the cusp axis at the junction of the three-pointed star. Compared to A. sudrei, less salient crests are present on the concave labial face of the crown in A. senegalensis nov. sp., as observable in type series (e.g. fig. 2 B). The ornamentation of the enameloid in the band of the lingual marginal face under transversal keel (as those of the labial face) is more finely developed compared to A. sudrei with alveolar network shape, except near the keel and crests where they reduce gradually. Only a few specimens of $A$. sudrei have been recovered in the Thanetian of Matam, Senegal (fig. $2 \mathrm{E}$ ). It seems more abundant in the Nigerian type locality (Cappetta, 1972) and in Togolese Thanetian deposits (Guinot et al., 2020). Although badly preserved (partial crown with broken cusp), the tooth crown shows that the cusp was mesiodistally flattened and that the junction between the low transverse keel and the cusp formed a three-pointed star in occlusal view. The enameloid of the crown concave labial face is also finely ornamented (fig. 2 E2). Some teeth from Ypresian deposits of Matam (e.g. fig. 2 F, H) show a morphology very close to that of $A$. sudrei teeth with a weak transverse keel. This probably indicates a close filiation between the two chronospecies of the new genus. Similar teeth to A. senegalensis were also observed (H.C. pers. observations) in the Ypresian of Morocco (Ouled Abdoun) and Mali (Tamaguilet), which might indicate that Atlantitrygon representatives had a wider distribution along the tropical western Atlantic coasts, from Niger to Morocco, during the ThanetianYpresian period. 
Superfamily DASYATOIDEA Whitley, 1940

Dasyatoidea INCERTAE FAMILIAE

Microtriftis nov.gen.

Type species: Microtriftis matamensis nov. sp.

Etymology: From Greek "triftis" refers to the rap shape of occlusal surface and "micro" relatively to the small size of teeth.

Diagnosis: the same that the unique species referred to this new genus.

Occurrence: Ypresian to Lutetian of Matam and Sine-Saloum region, Senegal

Microtriftis matamensis nov.sp.

Etymology: Refers to the Matam area where the type series was found.

Type material: Holotype Fig. 3 D, MAM-15 (well F0 9.18-9.3m, Unit 2 in Sambou et al., 2017) Ndendouri-Ouali Diala, ?Early Ypresian, Matam Fm.; Paratypes: MAM-12, 13, 14, 16, (well F0 9.18-9.3m, Unit 2 in Sambou et al., 2017), Ndendouri-Ouali Diala, ?Early Ypresian, Matam Fm., Senegal.

Additional material: about twenty teeth including those figured SNSAN/2011/05 to SNSAN/2011/07 (Fig. 3 F-H) - lower Lutetian (E8-E9 biozones, 49 to 45,8 My) of Sine Saloum region, Senegal.

Diagnosis: Myliobatoid ray with very small teeth (less than $1.3 \mathrm{~mm}$ in size) exhibiting reduced sexual dimorphism in crown morphology. The teeth of presumed breeding males have crown with small, lingually directed cusp, non-cuspidate teeth of presumed females (or from the lateral files of breeding males). The crown is robust, often diamond shaped in 
occlusal view with depressed visor suggesting a light teeth imbrication or at least a direct contact between alternating teeth. The lingual face of the crown is straight and mainly unornamented, excepted just under the transverse keel where it is slightly concave with an enameloid marked by vertical folders. The labial face is flat, strongly ornamented with sorted micrometric holes piercing the whole surface. The labial visor is medially concave and its ornamentation is less homogeneous compared to labial face. The teeth roots are bilobate, vertically directed, narrower than the crown and relatively high with two pinched lobes separated by large but soft nutritive groove where a unique large foramen opens medially.

Description: The teeth are very small, not exceeding $1.3 \mathrm{~mm}$ in size. They exhibit reduced sexual dimorphism in crown morphology, the crown teeth of presumed breeding males bearing a short cusp lingually directed (fig 3 A-B). The base of cusp is sometimes as wide as the transverse keel or medially centered (fig. 3 A-B). The non-cuspidate teeth of presumed females (conceivably teeth of non-breeding male or teeth from the lateral files of breeding males) display diamond-shaped occlusal outline. The holotype (fig. 3 D) probably belongs to a latero-anterior file of a female jaw. The crown is high with developed lingual face, which is sub-trapezoid in lingual view (fig. 3 D1). The lingual extremity is medially convex under the vertical bulge and the marginal borders are straight to slightly concave near the transverse keel. The enameloid is mainly unornamented except near the transverse keel where several enameloid folders are easily distinguishable (fig. 3 D1). The labial face is flat, its contour is diamond-shaped in occlusal view (fig. 3 D2) and displays many circular holes deeply piercing the enameloid surface (fig. 3 D3). The hole size is relatively homogenous except near the labial visor where the ornamentation is more unstructured. The labial visor is medially concave, which suggests a light imbrication with the lingual face of tooth directly anterior to it. The lower part of labial visor is thick and unornamented. The crown/root junction is located in a shallow depression in the centre of the basal crown surface. The root is narrower 
than the crown, of holaulacorhizous type with two lobes, which are semi-circular in shape in basal view. The root lobes are slightly lingually directed and almost vertical in profile. The root base displays a weak median nutritive groove that encloses a large central foramen. Male teeth (fig. 3 A-B) are similar in shape with a development of the medial cusp that could be high and as large than transversal keel, small (fig. 3 A) or reduced to a slight protuberanceof the transverse keel (fig. 3 B2). Such variability is probably due to different file position of the teeth, the higher teeth being possibly located near the symphysis. The female teeth are less variable, their crown being more or less narrow (fig. 3 C-D) or extended mesio-distally (fig.3 E). The lateral teeth have a mesio-distally extended labial face, a developed labial visor, a transverse keel slightly worn by functional wearing, and an oblique root lobe as in some extant myliobatoid with pavement-like dentition. Despite the limited sample of this minute species, teeth of female (fig. C-H) seem twice as large as those identified as belonging to male, conformably with expected size difference between sexes in most batoid species. No clear dental difference is obvious between specimens from the type series (Ypresian) and those from the Lower Lutetian (fig. 3 F-H).

Discussion: Currently, Microtriftis nov. gen. is only affiliated to dasyatoid of incertae familiae. If the morphology of isolated teeth (e.g. high crown with narrower root vertically oriented, flat ornamented labial face with concave visor in all files) suggests that each tooth is in contact with its neighbouring teeth to form a pavement-like dentition as observable in living myliobatoid, there are significant difference with their living and fossil representatives. In Microtriftis nov. gen., the root is always of holaulacorhizous type, like many dasyatoid but unlike myliobatoid that present a root of polyhaulacorhizous type. The imbrication of teeth (assumed here on alternating gridlines) seems light in Microtriftis nov. gen., the lingual face of tooth and the labial visor of previous tooth file could not be interlocked, in contrast to the condition observed in myliobatoid jaws. Other Paleogene dasyatoid incertae sedis developed 
a grinding dentition with joined alternating teeth (e.g. Heterobatis Noubhani and Cappetta 1997, Hypolophodon Cappetta 1980; Ishaquia Noubhani and Cappetta 1997; Myliodasyatis Noubhani and Cappetta 1997; Phosphatodon Cappetta 2012; Meridiana Case 1994). Among them, only Heterobatis can be reasonably compared to new genus, the other genera largely differing both in size and tooth morphology. The teeth of Heterobatis are also relatively small (until 3mm tooth size) with a flat labial face sharing ornamentation of enameloid. The anterior teeth display a clear dasyatid pattern with a crown face and a root directed lingually whereas the lateral teeth are sometimes very large, of polyhaulacorhizous type, and remind myliobatids.

The teeth of Microtriftis nov. gen. recall those of another Paleocene dasyatoid incertae sedis, Delpitia Noubhani and Cappetta 1997, with similar sexual heterodonty and ornamentation of the labial face. However, Delpitia is larger and possess a typical dasyatid root, directed lingually with lobes enlarged basally. No evidence of interconnecting/joining teeth is visible on type species D. reticulata (Noubhani and Cappetta 1997: Pl. 68, fig. 1-6). The minute new taxon is only recorded in Ypresian to Lower Lutetian marine deposits of Central and Northeastern Senegal (Sine-Saloum region and Matam) even if some early-middle Eocene specimens collected in well drilling from Guinea Bissau (Prian, 1986, 1987) are very similar (HC pers. observ.).

FIG.3 here

\section{NEOSELACHII Compagno, 1977 incertae ordinis}

Odontorhytis Böhm 1926

Type species: O. pappenheimi Böhm, 1926 
This enigmatical taxon is commonly recovered with other elasmobranchs in Eocene nearshore marine deposits of Africa and central Asia. Considering its uncertain systematic position among sharks, authors generally report its occurrence with some caution. Whatever the final outcome on systematic issues, this taxon could be a significant part of the Eocene neashore elasmobranch assemblages. Inappropriately attributed to a percoid fish or to a rajid by Priem (1905; 1915 respectively) based on middle-late Eocene Egyptian specimens, Böhm (1926) described similar teeth from Namibia as Odontorhytis pappenheimi, but also considered that it belongs to bony fish of family Lophiidae. Cappetta (1981) definitively attributed this taxon to an undetermined elasmobranch and figurated late Ypresian specimens from Ouled Abdoun (Morocco) that he attributed to the unique species $O$. pappenheimi of Böhm. However, and as noted Cappetta (2012 : 326), clear differences can be noted between Thanetian-Ypresian teeth on one side and middle-late Eocene teeth (e.g. O. pappenheimi Böhm, 1926) on the other side, asserting than late Ypresian material from Morocco and several other ones, must be likely considered as representatives of a distinct and unnamed species (Cappetta, 1987, 2012)

\section{Odontorhytis priemi nov. sp.}

Rajidae or Scylliidae Priem (1909: fig. 31-35)

Odontorhytis pappenheimi Cappetta (1981 plate 1 fig. 2-4)

Odontorhytis sp. Noubhani and Cappetta (1997: text only)

Odontorhytis sp. Gheerbrant et al. (1993: text only)

Odontorhytis sp. Cappetta (2012: fig. 313: C-E) 
Type material: Holotype: fig. 4 C, MAM-19 (well F0, 9.18-9.30 m, Unit 2 in Sambou et al., 2017) - Ndendouri-Ouali Diala, ?Early Ypresian, Matam Fm. ; Paratypes: MAM-18, MAM20 (well F3, Unit 2 in Sambou et al., 2017) Ndendouri-Ouali Diala, ?Early Ypresian, Matam Fm., Senegal.

Additional material: Sixteen teeth, partially broken, were mainly found in Thanetian (MAM22 to 24, well P53, Unit 0 in Sambou et al., 2017) and Ypresian levels of Ndendouri-Ouali Diala (Units 1-3 in Sambou et al., 2017). We can include those from Morocco: MYB8-9, DYD1-2 from Mera-el-arech (sillon A-B) and Recette 4 (Sillon D), Ouled Abdoun, Morocco - Late Ypresian, figured in Cappetta (1981 plate 1 fig. 2-4) and Cappetta (2012: fig. 313: CE).

Etymology: in honours to the French paleoichtyologist F. Priem (1857-1919) who firstly signalled material attributed to this new species.

Diagnosis: New species of Odontorhytis known by isolated teeth exhibiting reduced heterodonty. The new species is mainly characterized by teeth compressed mesio-distally, a fine cusp of sigmoidal profile with lateral cutting edges and marked enameloid folds on both face, a pair of very low lateral cusplets sometimes reduced to minute bulges in small specimens or simply lacking in the largest ones, the lack of lingual barb near the apex, and the lack of a sharp median crest on the crown labial face. The root is of cordiform outline in lingual or labial view, ever larger than crown with large median groove entirely developed on the root depth.

Occurrences: from Thanetian to Ypresian of North and Western Africa (e.g. Mali, Senegal, Morocco and Tunisia). 
Description: The variation of the tooth morphology in this elasmobranch genus is weak and only involved the presence/development of lateral cusplets compared to the overall/absolute size, which prevents any inference on possible developmental heterodonty. The teeth are small to medium in size and laterally compressed. The holotype is of medium size, probably from one of the anterior files (Fig. 4 C). The weakly enamelled cusp is high, pointed, and of sigmoid profile (fig. $4 \mathrm{C} 2$ ). The crown labial face is rather flat towards the apex of cusp but convex at its base where several fine folds run on its lower half. It extends downward, overlapping the root by an expansion, high and narrow, more or less pinched laterally (fig. 4 C1) that may bear a sagittal keel on the probably more anterior teeth (fig. 4 B1, H1). The lingual face of crown is strongly concave and bears parallel and well-marked vertical folds (fig. 4 C3). These folds rarely reach the apex of cusp but a short, sharp medio-sagittal crest is sometimes observable near the apex in some teeth (fig. 4 E1). The lateral cutting edges are well marked on the cusp but do not reach the base of the crown on many teeth, holotype included (fig. $4 \mathrm{C} 2$ ). At the base of the cusp, a pair of very low lateral denticles is usually visible near the onset of the cutting edges (fig. 4 F-H), one of the denticles can however disappear in some teeth (fig. 4 D) and could be reduced to tiny or inconspicuous bulges on more largest teeth, holotype included (fig. 4 B-C). The root is of cordiform outline in lingual view (fig. 4 B2, C3, E1), without well-differentiated lobes. In labial view, it extends well beyond the crown. Its basal face is very concave in profile (fig. 4 B3, C2, E2); it has a wellmarked lingual protuberance below the crown and displays an axial nutritive groove on all surface (fig. 4 C3). This groove is relatively deep at the level of the protuberance where a foramen opens (fig. 4 C3). Usually, the basal face lifts slightly on the edges of the groove (fig. 4 E1). Narrow small elliptical foramina open laterally on the labial surface of the root, near the crown-root boundary (fig. $4 \mathrm{C} 1$ ). Unfortunately, the Thanetian material (Fig 4 F-H) is poorly preserved in comparison to the Ypresian sample (fig. 4 B-E). However, the root 
morphology of the Thanetian teeth seemly resemble those of Ypresian teeth, but they are smaller, more often cuspidate, and their root outline seems sharper and less thick in profile.

Discussion: Compared to the middle-late Eocene representatives of genus (including $O$. pappenheimi, O. bahariensis Salame and Asan, 2019 and possible other unnamed species in Tabuce et al., 2005), the cusp is thinner, strongly bent lingually and of sigmoidal profile in $O$. priemi nov. sp. The lateral cutting edges are thin but distinct and always present in $O$. priemi nov. sp. They do not reach the crown base. A pair of very low and sharp lateral cusplets is sometimes present at the base of the cusp, near the beginning of cutting edges. These cusplets can be weak and sometimes be reduced to minute bulges or even absent in some teeth. The crown lingual face bears numerous fine folds that do not reach the apex. Compared to $O$. priemi nov. sp., a barb may be present on the lingual side of the apex in the middle-late Eocene specimens (e.g. O. pappeheimi, O. bahariensis). In the latter, the crown is more strongly mesio-distally compressed and slightly curved distally in labial view. No lateral cutting edge is visible on the cusp nor lateral cusplets at the base of crown. On the other side, an unusual distinct and sharp median crest is present on the cusp labial face, no crest -but similar fine folds- is present on the lingual face, which is transversally convex as observed in O. priemi nov. sp.

In both group, the root is high with a heart-like outline (particularly in $O$. priemi nov. sp.) but without differentiated lobes. The profile of its basal face is very concave; it shows a wellmarked lingual protuberance and bears an axial furrow on its whole surface. This furrow is much deeper at the end of protuberance where some foramina can be observed. The two groups of species differ from each other only by the morphology of the root (as the crown), which is mesio-distally compressed in $O$. pappeheimi and $O$. bahariensis compared to $O$. priemi nov. sp. There is an overlap in tooth size between $O$. priemi nov. sp. and $O$. pappenheimi/ O. bahariensis but the Thanetian-Ypresian species rarely reach more than $7 \mathrm{~mm}$ 
in height whereas the middle-late Eocene specimens can easily measure more than $1 \mathrm{~cm}$ in height (especially in $O$. pappenheimi). Distinction between $O$. pappenheimi and $O$.

bahariensis remains unclear. Without diagnosis, the latter seems to have smaller gracile teeth than in O. pappenheimi, with crown relatively higher with shorter labial cutting edge (Salame and Asan, 2019). Ignoring the ontogenetic heterodonty of this ambiguous neoselachian, $O$. bahariensis could in fact represent the youngest specimens of $O$. pappenheimi, usually recovered in the same areas and ages. The new species $O$. priemi nov. sp. is also present in the Ypresian of Mali (Cappetta 1987), Thanetian-Ypresian of Ouarzazate and phosphate of Ouled Abdoun, Morocco (Cappetta, 1981; Gheerbrant et al., 1993; Noubhani and Cappetta, 1997), and in phosphates of Redeyef, Tunisia (Priem, 1909). The second morphotype (including $O$. pappenheimi and ?O. bahariensis) also occurs in Senegalese deposits (Fig. 4 A) and was recovered in the top level of the Matam phosphate deposits (wells P1A, P1B, R4, I1 et G0 see Sambou et al. 2017) and in Sanghaye Bele water well, Sine-Saloum region. This morphotype is recovered elsewhere in the middle Lutetian of Morocco (Tabuce et al., 2005), in the late Lutetian-early Bartonian of Egypt (Strougo et al., 2007, Underwood et al., 2011, Salame and Asan, 2019) but seems more frequent in the late middle Eocene-late Eocene from southwestern Morocco (Adnet et al., 2010), Tunisia (Merzeraux et al., 2017; Sweydan et al., 2018), Egypt (Priem, 1905 ; Case and Cappetta, 1990 ; Murray et al., 2010; Adnet et al., 2011 ; Underwood et al., 2011 ; Murray et al., 2014), Namibia (Böhm 1926), and Pakistan (Case and West, 1991). Its occurrence in the early Rupelian of Jebel Qatrani-Quarry E, Fayum (Murray et al., 2014) is based on a unique broken tooth and must be confirmed by additional samples. These two species do not overlap in the fossil record, suggesting a replacement of taxa during the late Ypresian or near the Ypresian/Lutetian boundary. However, the youngest representatives of $O$. priemi nov. sp. from Matam (e.g. fig. 4 B) show a seemly transitional morphology toward those of "O. pappenheimi group" in having larger 
teeth, more compressed mesio-distally with no lateral cusplets. Murray et al. (2010) suggested that Odontorythis pappenheimi as the other elasmobranch elements from BQ-2 locality (Fayum, Egypt) probably represent freshwater-tolerant species. The co-occurrence of Odontorhytis teeth with mammals remains in different localities (e.g. Gheerbrant et al., 1993; Tabuce et al., 2005; Merzeraux et al., 2016; Murray et al., 2010, 2014; Tabuce et al., 2019) seems to confirm this ecological abilities even if the other listed occurrences, including those of Matam or Morocco, testify that it is firstly a marine elasmobranch.

FIG.4 here

\section{Paleobiological and Paleoecological inferences.}

Among Potamotrygonidae, which also include the marine Styracurinae (Carvalho et al., 2016), the sister subfamily Potamotrygoninae (South American river stingrays) is the most diverse and famous group of obligate freshwater stingrays. South American fossils of this subfamily drew particular attention this last decade (e.g. Brito and Deynat, 2004; Adnet et al., 2014; Chabain et al., 2017) with evidences that they were abundant in middle Eocene deposits of Peruvian Amazonia. In contrast, the living styracurines (amphi-American whipray) are less abundant. They are currently frequent in the Central eastern Pacific (Styracura pacifica) and Central western Atlantic (S. schmardae) shallow waters until the Amazon river mount southward (Last et al., 2016; Bloom and Lovejoy 2017). No fossil representatives of Styracurine (or formally Himantura) are known in fossiliferous deposits along the Central Eastern Pacific or Central Western Atlantic coasts (e.g. Landini et al., 2017; Carrillo-Bricenio et al., 2014, 2015, 2016, 2018). However, the styracurines likely inhabited the Eastern Pacific-Caribbean zone since the middle Eocene, which corresponds to the oldest occurrence of their sister taxa, the potamotrygonins (Adnet et al., 2014). The attribution of Atlantitrygon 
to Styracurinae is based on the similar overall shape of the teeth and the presence of a displaced main cusp. Further evidences (as coeval records in Caribbean zone) are needed to confirm such a systematic assumption but Atlantitrygon (and mainly the oldest species $A$. sudrei) might represent one of the marine-brackish pool species of potamotrygonid. Subsequently, the multiple occurrence of Atlantitrygon in Western Africa deposits may indicate that past styracurines were widespread in the Central Atlantic from western to eastern coasts during the warming period of Paleogene.

Solving the systematic affinities of Microtriftis among dasyatoid is out of scope of this study. The minute teeth seem partially interlocked forming the pavement-like teeth suited for crushing or grinding preys. Ornamented enameloid of labial surface in Microtriftis could probably strengthen the grater function of pavement-like teeth as observed in many other living and fossil taxa with such a dentition (e.g. Myliobatis, Rhombodus, Coupatezia, Dasyatis sensu lato, Pastinachus). Specialization for extreme durophagy, including an extremely robust dentition with pavement-like teeth, is redundant in myliobatiform evolution (e.g. Underwood et al. 2015, 2017). Their teeth can be only partially interlocked to crush preys, or can be strongly interfitted and jointed together thanks to complementary faces of crown to grind hard mollusc as observed in Myliobatidae and Rhinopteridae (grinding type). Microtriftis share the same interlocking pattern than many other fossil dasyatoid (e.g. Aturobatis, Heterobatis, Hypolophodon, Ishaquia, Meridiana, Myliodasyatis, Phosphatodon), which could also be considered as grinders (high crown, polygonal outline). However, the dentition of Microtriftis is unique in its extreme small size. The number of tooth files in Microtriftis jaws, as in all grinding taxa with holaulacorhize root (Cappetta 2012), was likely important. If we cannot surely estimate the size of occlusal surface of pavement of both jaws, it unlikely exceeded two centimetres in width considering the individual tooth size $(0.5 \mathrm{~mm})$. Living stingrays with interlocking plates of flat, pavement-like teeth are known to grind 
molluscs and other hard-shelled prey. Microtriftis then represents one of the smallest stingrays with grinding teeth, which raises the question on the type of preys it could predate on.

The Thanetian-Ypresian occurrence of the enigmatical Odontorythis completes the fossil record of the genus usually known by the middle-late Eocene. The tooth morphology of its oldest species Odontorythis priemi nov. sp. does not clarify its systematic position among Neoselachii. The presence of lateral cutting edges and additional cusplets is more common in shark teeth compared to the unusual morphology observed in Lutetian-Priabonian representatives, including its sister species $O$. pappenheimi. Observations of transitional forms between these two chronospecies $O$. priemi nov. sp. and $O$. pappenheimi and their relatives suggest that they progressively replaced each other during the latest early Eocene in Senegal and elsewhere.

\section{Conclusions.}

The Senegalese Paleogene fauna is significantly rich (see Pascal, 1987 and Sambou et al., 2017 for listing) with numerous other taxa recovered elsewhere. The focus on three new taxa described herein confirms the dating of fossiliferous levels of the phosphate series of Ndendouri-Ouali Diala (Matam) and improves the stratigraphical correlations between the phosphate deposits of Matam area and those of Sine-Saloum region during the Paleogene. The presence of Odontorhytis cf. pappenheimi and absence of $O$. priemi in the top level of the Matam Fm. (Matam area) and in Lam Lam Fm. in Sine-Saloum regions also confirm that both deposits are penecontemporaneous (see Tabuce et al., 2019). A previous study confirmed that the coquina limestone of the Lam Lam Fm. in Sanghaye Bele is subcontemporaneous with 
573 those of the clay-limestone unit ending the Matam Fm., and that it is indicative of a littoral 574 environment (Sambou et al. 2017).

575 The Gorgol Fm. (Thanetian) in Matam area probably corresponds to neritic deposal as 576 suggested by analysis of the elasmobranch fauna (Sambou et al., 2017) and lithology (Pascal, 577 1987). The presence of Atlantitrygon sudrei in Thanetian deposits of Senegal, Niger and Togo 578 suggests the establishment of an extended marine realm with faunal connection along the past 579 Guinea Gulf. During the lower Eocene period, the Senegal basins underwent a succession of 580 transgressions and regressions that install the mesobathyal and neritic deposits in the 581 southwestern region (Thiam, 2014; Thiam and Sarr, 2014). The Ypresian marine deposits in 582 the Matam area (lower part of Matam Fm.) are mainly dominated by limestones, clays, and phosphates deposited during the transgression phases that largely extended the marine area to the eastern edge of the Senegal basin (Monciardini and Pascal, 1966). A preliminary study of the elasmobranch fauna (see Sambou et al., 2017) enabled to reconstruct a continuous sea water communication with the large and deeper southermost gulf (Slansky, 1980) to the North

587 Gambia (Miyouna et al., 2009). Ostracods also testify that this inner platform was flooded by relative warm to temperate sea waters (Thiam and Sarr, 2018). Presence of Atlantitrygon senegalensis nov. sp. and Odontorhytis priemi nov. sp. in subcontemporaneous deposits of Mali and Morocco also suggests wider faunal connection along the Central Western Atlantic coasts during the Ypresian period. Coupled with some Ypresian tectonics (Miyouna et al 592 2009), the decrease of sea level began at the end of Ypresian as previously reported in 593 Casamance area (Ly AND Anglada, 1991) and in the Mbour-Joal area (Western Senegal; Sarr 1999). The strong decrease in selachian diversity recovered in the higher clay-limestone unit (top of Matam Fm.) coupled with the persistence of only small coastal species are clearly indicative of a more littoral environment in Matam (Sambou et al., 2017) with

597 contemporaneous development of anoxic conditions in southwestern plateform (Thiam and 
Sarr, 2018). However, the co-occurrence of Atlantitrygon senegalensis nov. sp. and

Odontorhytis cf. pappenheimi in the early Lutetian limestones of both localities also indicates the persistence of a relictual Est-West marine connection in central Senegal (between Matam and Sine-Saloum areas) during the early Lutetian regional regression (Thiam, 2014 ; Thiam and Sarr, 2014, 2018)

\section{Acknowledgements}

We thank the Department of Geology of the University Cheikh-Anta-Diop of Dakar, especially Professor El Hadji Sow (Head of Department). We are very grateful to Eugène N. Faye (Director of the SERPM, Société d'Etudes et de Réalisation des Phosphates de Matam) and El Hadji M. Fall (Director of MINTECH international) for providing full access to the quarry of Matam. . We are also grateful to Guillaume Guinot (University of Montpellier) for the data concerning the Paleocene record of Togo, Elisabeth Cabirou (University of Montpellier) for treatment of tooth illustrations, Giuseppe Marramà and anonymous reviewer for improving this work. This research is part of the PaleoSen project (www.paleosen.com), and was supported by the French ANR-PALASIAFRICA Program (ANR-08-JCJC-0017), PICS-CNRS, the International Exchange Scheme of the Royal Society, and the National Geographic Society's Global Exploration Fund (Northern Europe), and the Cooperation and Cultural Action Service of French Embassy in Senegal (N²019-0371853/SCAC/ESRI Programme d'Appui à la Recherche France Sénégal). Lionel Hautier also gratefully acknowledges Sidney Sussex College (Cambridge, UK).

\section{References}


625

626

627

628

629

630

631

632

633

634

635

636

637

638

639

640

641

642

643

644

645

646

Adnet, S., Cappetta, H., Elnahas, S., Strougo, A., 2011. A New Priabonian Chondrichthyans assemblage from the Western Desert, Egypt: Correlation with the Fayum Oasis. Journal of African Earth Sciences 61 (1), 27-37.

Adnet, S., Salas Gismondi, R., Antoine, P. O., 2014. Comparisons of Dental Morphology in River Stingrays (Chondrichthyes: Potamotrygonidae) with New Fossils from the Middle Eocene of Peruvian Amazonia Rekindle Debate on Their Evolution. Naturwissenschaften 101 (1), 33-45.

Arambourg, C., 1952. Les Vertébrés Fossiles Des Gisements de Phosphates (Maroc-AlgérieTunisie). Notes et Mémoires du Service géologique du Maroc 92, 1-372.

Beebe, W., Tee-Van, J., 1941. Eastern Pacific expeditions of the New York Zoological Society. XXVIII. Fishes from the tropical eastern Pacific. Part 3. Rays, Mantas and Chimaeras. Zoologica, Scientific Contributions of the New York Zoological Society 26 (3), $245-280$.

Bloom, D. D., Lovejo, N. R., 2017. On the Origins of Marine-Derived Freshwater Fishes in South America, Journal of Biogeography 44 (9), 1927-1938.

Böhm, J., 1926. Über tertiäre Versteinerungen von den Bogenfelsen diamantfeldern, In E. Kaiser (Edt.), Die Diamantwüste Südwestafrikas. Berlin. pp. 55-87.

Brito, P. M., Deynat, P. P., 2004. Freshwater Stingrays from the Miocene of South America with Comments on the Rise of Potamotrygonids (Batoids, Myliobatiformes), In Recent 
649

650

651

652

653

654

655

656

657

658

659

660

661

662

663

664

665

666

667

668

669

670

advances in the Origin and Early Radiation of Vertebrates, verlag Dr. Friedrich Pfeil:

München, Germany, pp 575-582.

Cappetta, H., 1972. Les Poissons Crétacés et Tertiaires Du Bassin Des Iullemmeden

(République du Niger). Palaeovertebrata 5 (5), 179-251.

Cappetta, H., 1980. Modification Du Statut Générique de Quelques Espèces de Sélaciens Crétacés et Tertiaires. Palaeovertebrata 10 (1), 29-42.

Cappetta, H., 1981. Additions a La Faune de Sélaciens Fossiles Du Maroc. 1: Sur La Présence Des Genres Heptranchias, Alopias et Odontorhytis Dans 1'Yprésien Des Ouled Abdoun.

Géobios 14 (5), 563-575.

Cappetta, H., 1987. Chondrichthyes II Mesozoic and Cenozoic Elasmobranchii. Schultze, H.P. (Edt.) Handbook of Paleoichthyology, Gustav Fischer Verlag: Stuttgart-New York. 193 p.

Cappetta, H., 2012. Chondrichthyes II Mesozoic and Cenozoic Elasmobranchii: Teeth.

Schultze, H.-P., (Edt.) Handbook of Paleoichthyology; verlag Dr. Friedrich Pfeil: StuttgartNew York. 512 p.

Cappetta, H., Traverse, M., 1988. Une Riche Faune de Sélaciens Dans Le Bassin à Phosphate de Kpogamé-Hahotoé (Eocène Moyen Du Togo): Note Préliminaire et Précisions Sur la Structure et l'âge du Gisement. Géobios 21 (3), 359-365. 
671 Carrillo-Briceño, J. D., Aguilera, O. A., Rodriguez, F., 2014. Fossil Chondrichthyes from the 672 Central Eastern Pacific Ocean and Their Paleoceanographic Significance. Journal of South 673 American Earth Sciences 51, 76-90.

674

675 Carrillo-Briceño, J. D., Maxwell, E., Aguilera, O. A., Sánchez, R., Sánchez-Villagra, M. R., 676 2015. Sawfishes and Other Elasmobranch Assemblages from the Mio-Pliocene of the South 677 Caribbean (Urumaco Sequence, Northwestern Venezuela). Plos One 10 (10), e0139230.

678

679

Carrillo-Briceño, J. D., Argyriou, T., Zapata, V., Kindlimann, R., Jaramillo, C. A., 2016. New 680 Early Miocene (Aquitanian) Elasmobranchii Assemblage from the La Guajira Peninsula, Colombia. Ameghiniana 53 (2), 77-99.

682

Carrillo-Briceño, J. D., Carrillo, J. D., Aguilera, O. A., Sanchez-Villagra, M. R., 2018. Shark 684 and Ray Diversity in the Tropical America (Neotropics) — an Examination of Environmental and Historical Factors Affecting Diversity. PeerJ 6, e5313.

686

687

Carvalho, M. R. D., Loboda, T. S., Da Silva, J. P. C. B., 2016. New Subfamily, Styracurinae, 688 and New Genus, Styracura, for Himantura Schmardae (Werner, 1904) and Himantura 689 Pacifica (Beebe and Tee-Van, 1941) (Chondrichthyes: Myliobatiformes). Zootaxa 4175 (3),

690 201-221.

691

692 Case, G. R., 1994. Fossil Fish Remains from the Late Paleocene Tuscahoma and Early 693 Eocene Bashi Formations of Meridian, Lauderdale County, Mississippi. Part I. Selachians. Palaeontographica Abteilung serie A 230 (4-6), 97-138. 
696

697

698

699

700

701

702

703

704

705

706

707

708

709

710

711

712

713

714

715

716

717

718

719

720

Case, G. R., Cappetta, H., 1990. The Eocene Selachians Fauna from the Fayum Depression in

Egypt. Palaeontographica Abteilung Serie A 212, 1-30.

Case, G. R., West, R. M., 1991. Geology and Paleontology of the Eocene Drazinda Shale Member of the Khirthar Formation, Central Western Pakistan, Part II Late Eocene Fishes. Tertiary Research 12 (3-4), 105-120.

Chabain, J., Antoine, P.-O., Altamirano-Sierra, A. J., Marivaux, L., Pujos, F., Salas Gismondi, R., Adnet, S., 2017. Cenozoic Batoids from Contamana (Peruvian Amazonia) with Focus on Freshwater Potamotrygonins and Their Paleoenvironmental Significance. Géobios 50 (5), $389-400$.

Claeson, K. M., Sarr, R., Hill, R. V., Sow, E. H., Malou, R., O’Leary, M. A., 2015. New Fossil Scombrid (Pelagia: Scombridae) Fishes Preserved as Predator and Prey from the Eocene of Senegal. Proceedings of the Academy of Natural Sciences of Philadelphia 164 (1), $133-147$.

Dartevelle, E., Casier, E., 1943. Les Poissons Fossiles Du Bas-Congo et Des Région Voisines. Annales du Musée du Congo Belge, Série A (Minéralogie Géologie, Paléontologie) 3- 2 (1), $1-200$.

Dartevelle, E., Casier, E., 1959. Les Poissons Fossiles Du Bas Congo et Des Région Voisines. Annales du Musée du Congo Belge, Série A (Minéralogie Géologie, Paléontologie) 3- 2 (3), $257-568$. 
Flicoteaux, R., 1974. Biozonation des formations paléogènes de la retombée orientale du 722 723 724

dôme de Ndias (Sénégal occidental). Vth African Colloquium on Micropalaeontology, AddisAbeba, Ethiopia, 1972, Madrid, Enadimsa p. 349-362.

Guinot, G., Adnet, S., Shimada, K., Underwood, C. J., Siversson, M., Ward, D. J., Kriwet, J., Cappetta, H., 2018. On the Need of Providing Tooth Morphology in Descriptions of Extant Elasmobranch Species. Zootaxa 4461 (1), 118-126.

Guinot, G., Amoudji, Y.Z., Kassegne, K.E., Sarr, R., Johnson, A.K.C., Da Costa, P.Y.D., Hautier, L., 2020. Elasmobranchs from the upper Palaeocene of Togo. Géobios, in press. https://doi.org/10.1016/j.geobios.2019.12.003.

Gheerbrant, E., Cappetta, H., Feist, M., Jaeger, J. J., Sudre, J., Vianey-Liaud, M., Sige, B., 1993. La Succession Des Faunes de Vertébres d'age Paléocène Supérieur et Éocène Inférieur Dans Le Bassin d'Ouarzazate, Maroc. Contexte Géologique, Portée Biogéographique et Paléogéographique. Newsletters on Stratigraphy 28 (1), 35-58.

Hautier, L., Sarr, R., Tabuce, R., Lihoreau, F., Adnet, S., Domning, D. P., Samb, M., Hameh, P. M., 2012. First Prorastomid Sirenian from Senegal (Western Africa) and the Old World Origin of Sea Cows. Journal of Vertebrate Paleontology 32 (5), 1218-1222.

Hautier, L., Sarr, R., Lihoreau, F., Tabuce, R., Marwan Hameh, P., 2014. First record of the family Protocetidae in the Lutetian of Senegal (West Africa). Palaeovertebrata 1-7, $10.18563 /$ pv.38.2.e2 
Landini, W., Altamirano-Sierra, A., Collareta, A., Di Celma, C., Urbina, M., Bianucci, G., 2017. The Late Miocene Elasmobranch Assemblage from Cerro Colorado (Pisco Formation, Peru). Journal of South American Earth Sciences 73, 168-190.

Last, P. R., De Carvalho, M. R., Corrigan, S., Naylor, G. J., Séret, B., Yang, L., 2016. The Rays of the World, CSIRO Publishing, Melbourne. 40, 790 pp.

Ly, A., Anglada, R., 1991. Le bassin sénégalo-mauritanien dans l'évolution des marges périatlantiques au Tertiaire. Cahier de Micropaléontologie. Nouvelle Série 6 (2), 23-47.

Merzeraud, G., Essid, E. M., Marzougui, W., Ammar, H. K., Adnet, S., Marivaux, L., Tabuce, R., Vianey-Liaud, M., 2016. Stratigraphie et Sédimentologie Des Dépôts Marins et Continentaux d'âge Éocène Moyen à Miocène en Tunisie Centrale (Région Du Djebel El Kébar). Bulletin de la Société Géologique de France 187 (1), 11-25.

Miyouna, T., Sow, E.H., Diop, A., Ndiaye, P.M., Niang Diop, I., 2009. Evolution Morphostructurale et bathymétrique de la partie Septentrionale du bassin Sénégalais au Paléogène. Journal des Sciences 9 (1), $1-16$.

Monciardini, C., Pascal, M., 1966. Recherche de phosphates. Rapport complémentaire. Le phosphate de chaux au Sénégal. Synthèse des résultats acquis, étude paléogéographique et essai prévisionnel. Rapport du BRGM, DAK 66 A8, 31p (1) 
777

Murray, A. M., Cook, T. D., Attia, Y. S., Chatrath, P., Simons, E. L., 2010. A Freshwater Ichthyofauna from the Late Eocene Birket Qarun Formation, Fayum, Egypt. Journal of Vertebrate Paleontology 30 (3), 665-680

Murray, A. M., Argyriou, T., Cook, T. D., Sues, H.-D., 2014. Palaeobiogeographic

Relationships and Palaeoenvironmental Implications of an Earliest Oligocene Tethyan Ichthyofauna from Egypt. Canadian Journal of Earth Sciences 51 (10), 909-918.

Noubhani, A., Cappetta, H., 1995. Batoïdes Nouveaux Ou Peu Connus (Neoselachii: Rajiformes, Myliobatiformes) des Phosphates Maastrichtiens et Paléocènes du Maroc. Belgian Geological Survey, Professional Paper 278, 157-183.

Noubhani, A., Cappetta, H., 1997. Les Orectolobiformes, Carcharhiniformes et Myliobatiformes (Elasmobranchii, Neoselachii) Des Bassins à Phosphate Du Maroc (Maastrichtien-Lutétien Basal). Systématique, Biostratigraphie, Évolution et Dynamique Des Faunes. Palaeo Ichthyologica 8, 1-327.

O’Leary, M.A., Sarr, R., Malou, R., Sow, E.H., Lepre, C., Hill, R.V., 2012. A new fossil amiid from the Eocene of Senegal and the persistence of extinct marine amiids after the Cretaceous-Paleogene boundary. Copeia 4, 603-608.

Pascal, M. 1987. Nouvelles découvertes de minéralisations phosphatées au Sénégal: les gisements de N'Diendouri-Ouali Diala (Département de Matam, Région du Fleuve), Chronique de la recherche minière $486: 3-24$. 
796

797

798

799

800

801

802

803

804

805

806

807

808

809

810

811

812

813

814

815

816

Prian, J.P., 1986. Géologie de la bordure méridionale du golfe tertiaire de Casamance

(Sénégal, Guinée Bissau). Document du BRGM n¹01, ISSN 0221-2536, 5-32.

Prian, J. P., 1987. The Farim-Saliquinhe Eocene phosphate deposits Guinea Bissau, West Africa. In : Phosphate deposits of the World Vol. 2 Phosphate rock resources. Notholt, A.J.G, Sheldon, R.P., Davidson, D.F. (Edt.), Cambridge University press, pp. 277-283.

Priem, M. F., 1905. Sur les poissons fossiles de l'Eocène moyen d'Egypte. Extrait du Bulletin de la Société Géologique de France 4 V, 633-641.

Priem, M. F., 1909. Note Sur Les Poissons Fossiles Des Phosphates de Tunisie et d'Algérie.

Extrait du Bulletin de la Société Géologique de France 4 IX, 315-324.

Priem, M. F., 1915. Sur Les Vertébrés Du Crétacé et de l'Eocène d’Egypte. Extrait du Bulletin de la Société Géologique de France 4 XIV, 366-382.

Roger, J., Noël, B.J., Barusseau, J. P., Serrano, O., Nehlig, P., Duvail, C., 2009. Notice explicative de la carte géologique du Sénégal à 1/500 000, feuilles nord-ouest, nord-est et sudouest. Ministère des Mines, de l'Industrie et des PME, Direction des Mines et de la Géologie, Dakar, $61 \mathrm{p}$.

Salame, I., Asan, A., 2019. A new Odontorhytis species (Chondrichtyes) from the middle Eocene of Elgedida Mine, Bahariya Oasis, Egypt. Egyptian Journal of Geology 63, 407-415. 
Sambou, B. S., 2018. Etudes sédimentologique, biostratigraphique et paléoenvironementale des séries phosphatées du gisement Paléogène de la région de Matam (Sénégal), Unpublished thesis, Université Cheikh Anta Diop Dakar, 1-200

Sambou, B. S., Sarr, R., Hautier, L., Cappetta, H., Adnet, S., 2017. The Selachian Fauna (Sharks and Rays) of the Phosphate Series of Ndendouri-Ouali Diala (Matam, Western Senegal): Dating and Paleoenvironmental Interests. Neues Jahrbuch für Geologie und Paläontologie Abtheilung 283 (2), 205-219.

Sarr, R., 1999. Le Paléogène de la région de Mbour-Joal (Sénégal occidental): biostratigraphie, étude systématique des ostracodes, paléoenvironnement. Revue de Paléobiologie, Genève 18 (1), 1-29.

Solé, F., Noiret, C., Desmares, D., Adnet, S., Taverne, L., De Putter, T., Mees, F., Yans, J., Steeman, T., Louwye, S., Folie, A., Stevens, N.J, Gunnel, G.F., Baudet, D., Kitambala Yaya, N ., Smith, T., 2018. Reassessment of Historical Sections from the Paleogene Marine Margin of the Congo Basin Reveals an Almost Complete Absence of Danian Deposits. Geoscience Frontiers $10(3), 1039-1063$.

Stevens, N. J., Eastman, J. T., Odunze, S. O., Cooper, L. N., Obi, G. C., 2011. Paleocene Ichthyofauna and Paleoenvironmental Setting, Imo Formation, Southeastern Nigeria. Neues Jahrbuch für Geologie und Paläontologie Abhteilung 260 (3), 289-296.

Strömer, E., 1910. Reptilien-Und Fischreste Aus Dem Marinen Alttertiär von Südtogo (Westafrika). Monatsbericht der deutschen geologischen Gesellschaft 62 (7), 478-505. 
Strougo, A., Cappetta, H., Elnahas, S. A., 2007. Remarkable Eocene Ichthyofauna from the

ElGedidia Glauconitic Sandstone, Bahariya Oasis, Egypt, and Its Stratigraphic Implications,

MERC Ain Shams University, Earth Sciences Series 21, 81-98.

847

Tabuce, R., Adnet, S., Cappetta, H., Noubhani, A., Quillevéré, F., 2005. Aznag (Bassin d'Ouarzazate, Maroc), Nouvelle Localité à Sélaciens et Mammifères de l'Eocène Moyen

Tabuce, R., Sarr, R., Adnet, S., Lebrun, R., Lihoreau, F., Martin, J., Sambou, B., Thiam, M.,

Hautier, L., 2019. Filling a gap in the proboscidean fossil record: a new genus from the

Lutetian of Senegal. Journal of Paleontology, in press. doi.org/10.1017/jpa.2019.98

Thiam, M., 2014. Etudes biostratigraphiques et paleoenvironnementales du Cénozoique de la marge continentale ouest africaine en Casamance (Sénégal) d'après les ostracodes et les foraminifères. Unpublished thesis, Université Cheikh Anta Diop Dakar, 1-208

859

Thiam, M., Sarr, R., 2014. Etude des paléoenvironnements du Paléocène au Miocène du bassin sédimentaire sénégalais (Casamance, Afrique de l'Ouest) par analyse factorielle des populations de foraminifères benthiques. Revue de Paléobiologie, Genève 33 (1), 143-157. 
871

872 Underwood, C. J., Johanson, Z., Welten, M., Metscher, B., Rasch, L. J., Fraser, G. J., Smith, 873 M. M., 2015. Development and Evolution of Dentition Pattern and Tooth Order in the Skates 874 875

876

Underwood, C. J., Ward ,D. J., King, C., Antar, S. M., Zalmout, I. S., Gingerich, P. D., 2011.

Shark and Ray Faunas in the Middle and Late Eocene of the Fayum Area, Egypt. Proceedings of the Geologists' Association 122 (1), 47-66.

And Rays (Batoidea; Chondrichthyes). Plos One 10 (4), e0122553.

Underwood, C. J., Kolmann, M. A., Ward, D. J., 2017. Paleogene Origin of Planktivory in the Batoidea. Journal of Vertebrate Paleontology 37 (3), e1293068.

Vandenberghe, N., Hilgen, F.J.,Speijer, R.P., 2012. The Paleogene Period. In: Gradstein, F. M., Ogg, J. G., Schmitz, M. D., and Ogg, G. M., (Edts.) The Geological Time Scale 2012, Oxford, Elsevier Science, p. 855-921

Werner, F., 1904. Die Fische der zoologisch-vergleichend-anatomischen Sammlung der Wiener Universität. I. Teil. Cyclostomen, Chondropterygier, Ganoiden, Dipnoer. Zoologische Jahrbücher, Abteilung für Systematik, Geographie und Biologie der Tiere (Jena) 21 (3), 263302.

White, E. I., 1926. Eocene Fishes from Nigeria. Bulletin of the Geological Survey Nigeria 10, $1-82$.

White, E. I., 1934. Fossil Fishes of Sokoto Province. Bulletin of the Geological Survey Nigeria 14, 1-78. 
893

894 White, E. I., 1955. Notes on African Tertiary Sharks. Bulletin of the Geological Society

$895 \quad$ Nigeria 5 (3), 319-325.

896

897

898

899

900

901 


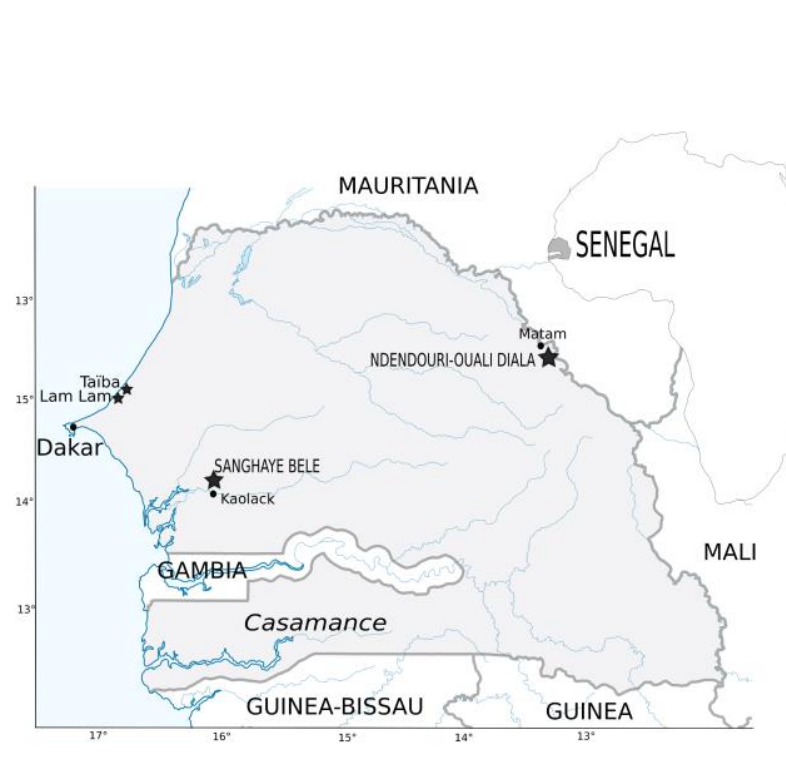

902

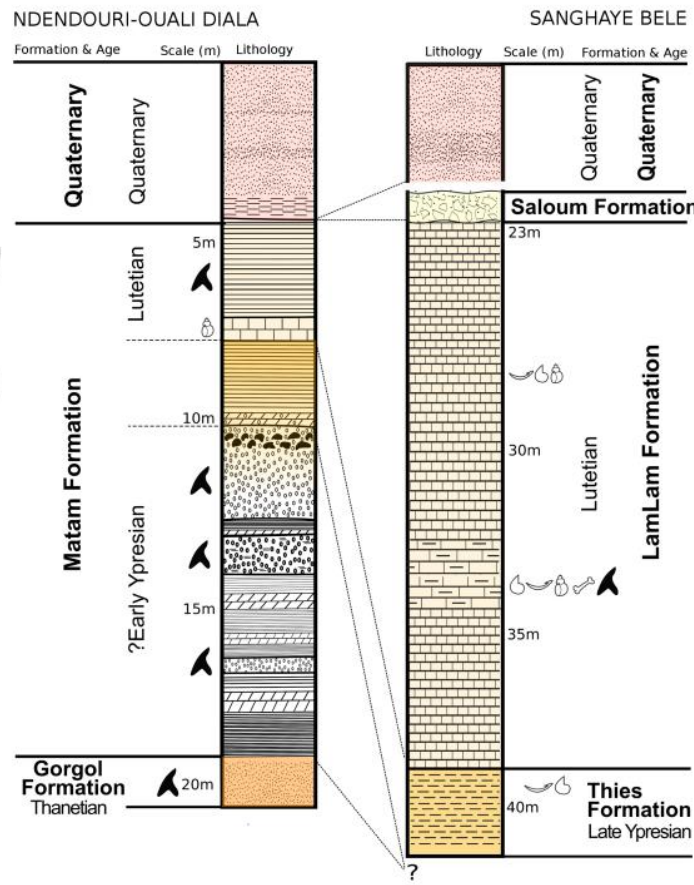

903 Fig. 1. Location and hypothetical stratigraphic correlation of Senegal Paleogene deposits

904 between studied fossil localities of Sanghaye Bele and Ndendouri-Ouali Diala. Logs and

905 details from Tabuce et al. (2019) and Sambou et al. (2017), respectively. Black teeth outline

906 indicating levels with elasmobranch remains.

907 Fig. 1. Localisation et hypothèse de corrélation stratigraphique des gisements paléogènes du

908 Sénégal entre les localités fossilifères étudiées de Sanghaye Bélé et Ndendouri-Ouali Diala.

909 Logs et détails des coupes issus de Tabuce et al. 2019 et Sambou et al. 2017, respectivement.

910 Les silhouettes des dents noires indiquent les niveaux avec les restes d'élasmobranches. 


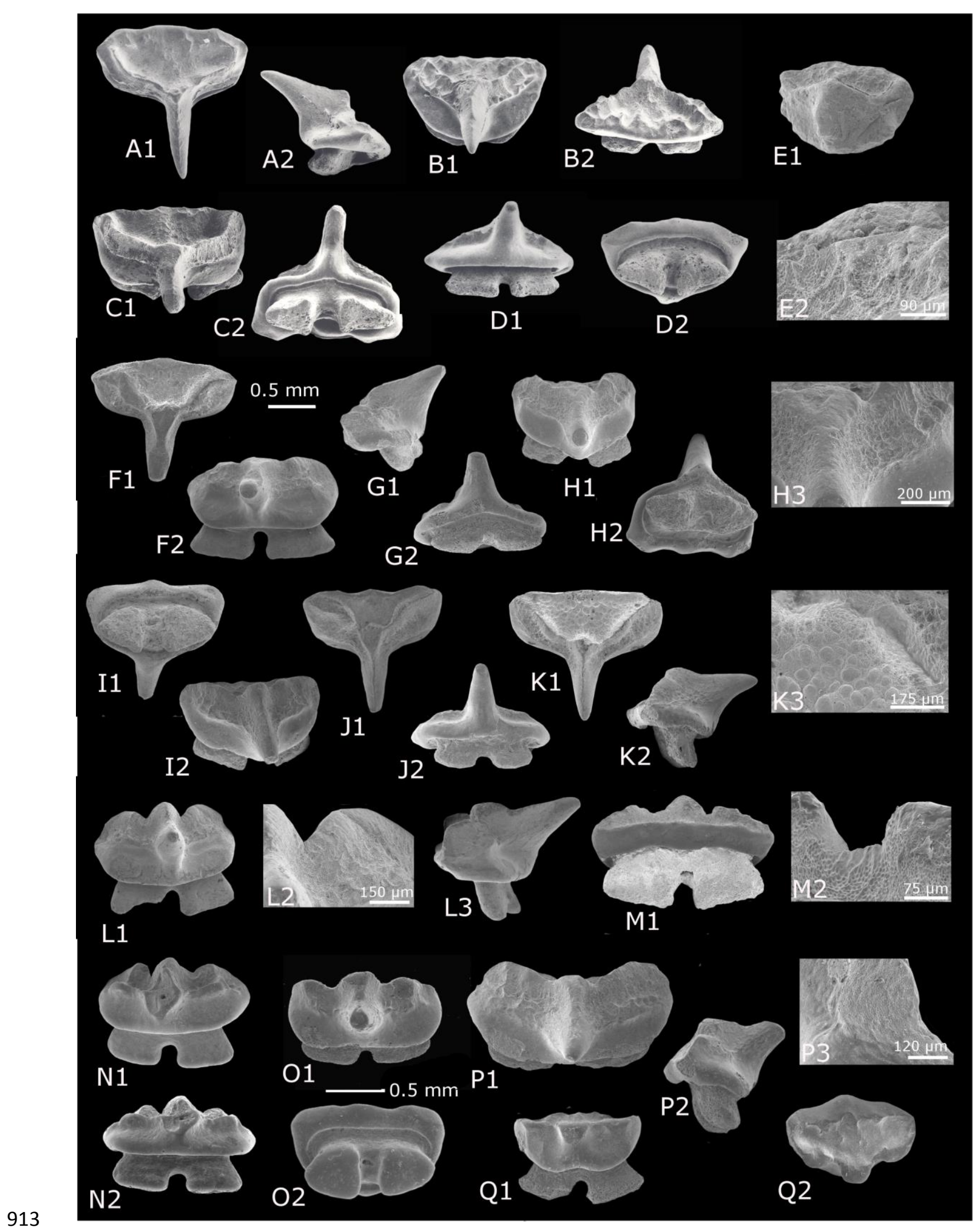

914 Fig. 2. Atlantitrygon sudrei nov. sp.: Thanetian of Sessao, Niger - Fig. A. SES64 (holotype); B. SES65; C. SES62; D. SES63; E. MAM-03 (well P53, Unit 0 in Sambou et al., 2017) ; 
916 Atlantitrygon senegalensis nov. sp.: Fig F-J: MAM-04 to MAM-08; Fig. K: MAM-09

917 (holotype); Fig. L-M: MAM-10 to MAM-11 (well F0 9.18-9.3m, Unit 2 in Sambou et al., 918 2017) ?Early Ypresian, Matam Fm. ; Fig. N-Q. SNSAN/2011/01 to SNSAN/2011/04 Lower 919 Lutetian, Lam Lam Fm.

920 Fig. 2. Atlantitrygon sudrei nov. sp.: Thanétien de Sessao, Niger - Fig. A. SES64 (holotype); 921 B. SES65; C. SES62; D. SES63; E. MAM-03 (puits P53, Unité 0 dans Sambou et al., 2017); 922 Atlantitrygon senegalensis nov. sp.: Fig F-J: MAM-04 à MAM-08; Fig. K: MAM-09 923 (holotype); Fig. L-M: MAM-10 à MAM-11 (puits F0 9.18-9.3m, Unité 2 dans Sambou et al., 924 2017) ?Yprésien inférieur, Formation de Matam; Fig. N-Q. SNSAN/2011/01 à 925 SNSAN/2011/04 Lutétien inférieur, Formation de Lam Lam. 


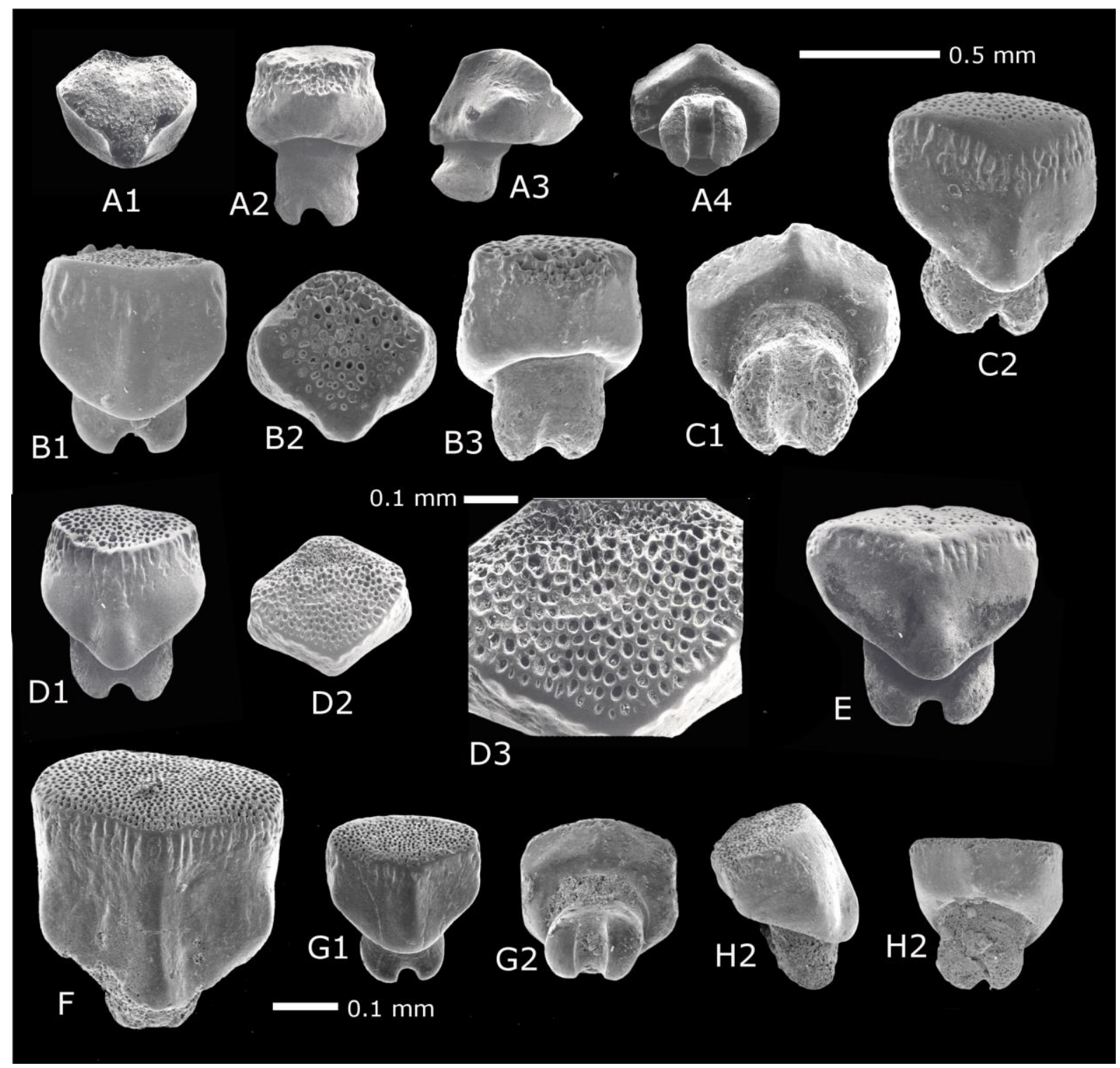

Fig. 3. Microtriftis matami nov. gen. nov. sp. A MAM-12 (well F0 9.18-9.3m, Unit 2 in

Sambou et al., 2017) ?Early Ypresian, Matam Fm.; B-C MAM-13 and MAM-14 (well P1,

Unit 2 in Sambou et al., 2017) ?Early Ypresian, Matam Fm.; D-E MAM-15 (holotype) and

MAM-16 (well F0 9.18-9.3m, Unit 2 in Sambou et al., 2017) ?Early Ypresian, Matam Fm.; F-

H SNSAN/2011/05 to SNSAN/2011/07 Lower Lutetian, Lam Lam Fm.

Fig. 3. Microtriftis matami nov. gen. nov. sp. A MAM-12 (puits F0 9.18-9.3m, Unité 2 dans 
937 ?Yprésien inférieur, Formation de Matam ; F-H SNSAN/2011/04 à SNSAN/2011/07 Lutétien 938 inférieur, Formation de Lam Lam.

939 


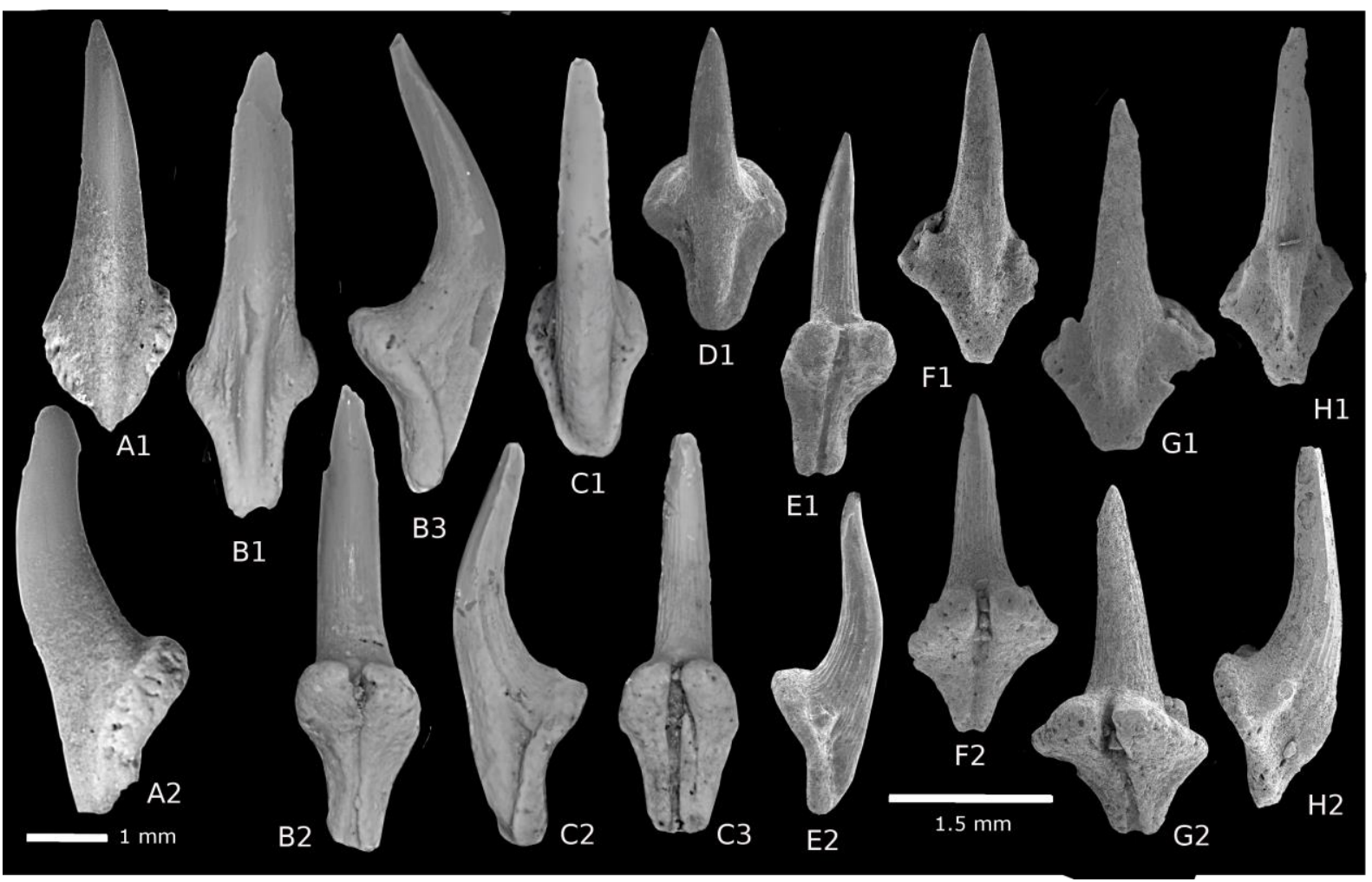

Fig. 4. A. O. cf. pappenheimi: Lower Lutetian, Lam Lam. Fm., SNSAN/2011/08; B-F.

Odontorhytis priemi nov.sp., : B: MAM-18 from (well F3, Unit 2 in Sambou et al., 2017)

?Early Ypresian, Matam Fm., C: MAM-19 (well F0 9.18-9.3m, Unit 2 in Sambou et al., 2017)

(holotype) ?Early Ypresian, Matam Fm, D: MAM-20 (well F3, Unit 2 in Sambou et al., 2017)

?Early Ypresian, Matam Fm; E: MAM-21 (well P1A, Unit 2 in Sambou et al., 2017) ?Early

Ypresian, Matam Fm ; F-H MAM-22 to MAM-24 (well P53, Unit 0 in Sambou et al., 2017); Thanetian, Gorgol Fm.

Fig. 4. A. O. $c f$. pappenheimi: Lutétien inférieur, Formation de Lam Lam, SNSAN/2011/08; B-F. Odontorhytis priemi nov.sp., : B: MAM-18 de (puits F3, Unité 2 dans Sambou et al., 2017) ?Yprésien inférieur, Formation de Matam, C: MAM-19 (puits F0 9.18-9.3m, Unité 2 dans Sambou et al., 2017) (holotype) ?Yprésien inférieur, Formation de Matam, D: MAM-20 (puits F3, Unité 2 dans Sambou et al., 2017) ?Yprésien inférieur, Formation de Matam; E: MAM-21 (puits P1A, Unité 2 dans Sambou et al., 2017) ?Yprésien inférieur, Formation de 
954 Matam; F-H MAM-22 à MAM-24 (puits P53, Unité 0 dans Sambou et al., 2017); Thanétien,

955 Formation de Gorgol.

956 